\title{
Psychiatric aspects of AIDS
}

\author{
Daniela Bundalo-Vrbanac ${ }^{1}$, Danijel Buljan ${ }^{1}$, Ivana Sindik ${ }^{1}$, \\ Ana Kovak-Muficí ${ }^{1}$, Davor Zdunić ${ }^{1}$, Mirjana Orban ${ }^{2}$ \\ ${ }^{1}$ Department of Psychiatry, University Hospital Center »Sestre milosrdnice«, Zagreb, Croatia \\ ${ }^{2}$ Clinic for Psychiatry Pet Plus, Zagreb, Croatia
}

\begin{abstract}
AIDS is a multimorbid, severe and complex medical illness accompanied with psychiatric disorders and a strong stigma and discrimination of the people that are affected. Appearance of standard antiretroviral therapy and CART (combination antiretroviral therapy) reduced the morbidity rates of AIDS, but the incidence of AIDS is still on the rise. There are about 34 million people infected with AIDS worldwide. With the annual number of new AIDS cases less than 4 per million in the total population, Croatia is a country that has continuously had a very low incidence of the disease. Given that patients with AIDS live longer today, they are prone to psychological problems related to living with a chronic illness. Thus, psychiatric care is an essential part of a multidisciplinary treatment.
\end{abstract}

Key words: AIDS, anxiety-depressive disorder, psychotic disorder, delirium, cognitive disorders, pain syndrome.

\section{INTRODUCTION}

AIDS (acquired immunodeficiency syndrome) is a multi-morbid, severe and complex medical illness accompanied by psychiatric disorders and a strong stigma and discrimination of the people that are affected. Appearance of standard antiretroviral therapy and CART (combination antiretroviral therapy), reduced the morbidity rates of AIDS, but the incidence of AIDS is still on the rise. The most significant causes of

Correnspodence to: Daniela Bundalo Vrbanac, Department of Psychiatry, University Hospital Center »Sestre milosrdnice«, Vinogradska c. 29, Zagreb, Croatia, e-mail dbundalovrbanac@yahoo.com 
HIV (human immunodeficiency virus) infection spread are lack of education and information, inadequate educational programs, an increased number of drug users, increase of prostitution, liberal sexual behavior, etc. HIV is spread among men, women and children of different ages, ethnicities, sexual orientation, socioeconomic classes and cultural backgrounds. Considering the medical complications that HIV-infected are exposed to, the disease can cause a range of psychiatric problems that are encountered in the context of consultation-liaison psychiatry. ${ }^{1,2}$

\section{Epidemiology}

HIV infects about 14000 people worldwide on daily basis, and 50\% of infected people are 14 to 24 years old. There are about 34 million people infected with AIDS worldwide. During 2010, 2.7 million people were infected and about 1.8 million people died from AIDS, mainly due to the unavailability of therapy. AIDS has become the leading cause of death in Africa and the fourth leading cause of death worldwide.

Early diagnosis and antiviral treatment significantly reduces mortality. In 2010, compared to mortality rates in 2005, mortality was reduced by $21 \%$. Since 1985 (when the first cases of HIV infection in Croatia were reported) to 2010, out of 862 registered persons diagnosed with HIV infection in Croatia, 325 developed AIDS. In the same period, 176 of patients with AIDS died. In 2010, a stable trend has continued with a 19 new registered cases of AIDS, and a slight decrease of morbidity due to available therapy. With the annual number of new AIDS cases less than 4 per million in the total population, Croatia is a country that has continuously had a very low incidence of the disease due to the continuous systematic surveillance, prevention, control and treatment of the disease. ${ }^{3}$

Simultaneously, there is an increase in the number of newly diagnosed cases of HIV infection which is partly explained with the increase of HIV infection worldwide, and partly with the intensive search for infected through voluntary, free and anonymous testing and counseling. Among all persons with HIV infection, 85\% are men, and most infections are registered in the group from 25 to 49 years of age. The sexual transmission of infection is dominant, in $51 \%$ of cases the infection transmission path was a homosexual intercourse between men. In $34 \%$ of cases transmission path was heterosexual intercourse, often associated with living abroad, sex trade and a frequent change of sexual partners. About $7 \%$ of diagnosed patients were infected by sharing the equipment for intravenous drug use, and all other ways of transmission (blood transfusion, transmission from mother to child) sum up to less than 5\% of those infected. During the last 20 years, Croatia has been a country that, despite the 
»war epidemic « of opiate addiction, continuously had a very low incidence of the disease and the proportion of HIV positive intravenous opiate addicts was very low and had shown a stable trend (0.5\% in 2009 and 2010). In 2010 (from the total of 237 intravenous drug users), and in 2009 (from the total of 329 tested for HIV infection), a positive finding has not been registered among intravenous drug users. The low percentage of infected intravenous drug users is due to continuous education, modern pharmacotherapy, work counseling and treatment, needle and syringe exchange programs, and other prevention measures implemented continuously since $1986 .{ }^{4}$

\section{Psychiatric disorders and AIDS}

\section{The psychological consequences of sero-conversion}

After being diagnosed with HIV, patients pass through stages similar to those described in the case of cancer and impending death. During the initial crisis, patients experience intense feelings, they are in shock, angry, scared and in denial. Usually they do not believe the first diagnosis and seek re-testing and a second opinion. When the period of denial passes, patients become upset and angry. In the transitional stage denial is replaced with guilt, self-pity, depression and rebellion (»if I have to die, then I can easily take drugs and be happy «). When patients reach the stage of acceptance, it is common to develop a combative attitude towards the disease and to activate in gathering the new information about the treatment alternatives and options that are offered. It is possible that some patients attempt to establish a connection with the people they have lost contact with, some will write wills determining who will take care of them when they are no longer able to take care of themselves and some will plan their funeral. It is significant to remember that there are no clear boundaries between the phases and that stages may overlap..$^{5-7}$

\section{Depression and HIV}

Major depressive disorder is the most common psychiatric disorder that HIV infected patients suffer from. Some of the research suggest that depression occurs in about $30 \%$ of patients. Suicide is a tragic and common complication of depression and the stigma associated with AIDS. Furthermore, antiviral therapy (CART) has chronic side effects (such as metabolic abnormalities, gastrointestinal side effects and lipodystrophy), which can be demoralizing and cause depression.

All antidepressants are equally effective in the treatment of AIDS, and their effect is faster and smaller doses are required then with patients that are not infected with HIV. Given that infected patients are particularly susceptible to the side effects of 
psychotropic medications, the SSRI antidepressants (selective serotonin reuptake inhibitors) are recommended. Suicide is preventable if depression is diagnosed and properly treated. Also, HIV infected patients take a large number of medications, drug interactions can be expected between antidepressants and other drugs. ${ }^{8,9}$

\section{Anxiety and HIV}

Anxiety often occurs, especially after the initial diagnosis of HIV infection. Many patients tend to conceal their HIV status, sexual orientation, use of illegal drugs and medications, all of which cause additional anxiety. PTSD-like syndrome was observed in patients in the time of sero-conversion. In this population, we confront a whole range of anxiety disorders from adjustment disorders to panic disorder and agoraphobia. It should be born in mind that anxiety may take the form of a somatic symptom. Anxiety can be treated with pharmacological and non-pharmacological therapy. Among the anxiolytic drugs, benzodiazepines are the first choice drug, but with limited time of use because of their tendency to cause addiction.

For more chronic anxiety, SSRIs or buspirone are recommended. Non-pharmacological methods include individual and group psychotherapy, meditation, muscle relaxation, hypnosis and biofeedback. ${ }^{9-12}$

\section{Psychotic disorders and HIV}

The frequency of psychosis in HIV patients is very variable. Psychosis can be a primary diagnosis or a secondary diagnosis during treatment of an existing medical condition. Psychosis among HIV patients can be caused by a number of factors: opportunistic infections, the direct effects of HIV on the brain, the side effects of drugs and other medical treatments, symptom of substance abuse, intoxication, withdrawal or conventional psychiatric disorders such as schizophrenia and bipolar disorder. ${ }^{11}$

Given that these patients are particularly susceptible to the side effects of antipsychotic drugs, newer atypical antipsychotics are recommended for the treatment (risperidone, olanzapine, quetiapine), and if haloperidol is used, it should be given in very low doses. ${ }^{12,13}$

\section{Cognitive disorders and HIV}

In the case of HIV infection, the AIDS cognitive disorder could be a mild cognitive motor disorder or dementia associated with HIV (HIV associated dementia-HAD).

Mild cognitive-motor disorder is diagnosed when following symptoms occur: impaired attention and concentration, mental slowing, impaired memory, slowed movements, impaired coordination, change in personality. 
Dementia associated with HIV is a common diagnosis among younger and older patients.

HAD occurs in the later stages of the disease, and specific risk factors for this are older age, weakening syndrome, anemia and a history of taking drugs.

Dementia, which is found in patients infected with HIV is similar to subcortical dementia encountered in Parkinson's or Wilson's disease. In early HAD, symptoms can include apathy, slowed information processing, difficulties in performing automated tasks, unsteady pace or lack of coordination, slight tremors, forgetfulness and visual-constructive deficits. In the late HAD, symptoms include psychotic features, attention deficit difficulties, severe memory loss, personality changes, ataxia, powerful tremor, deprivation of speech, illusions and hallucinations. Dementia associated with HIV is reversible because antiviral therapy leads to improvement of cognitive deficits. CART therapy reduces severity and slows the progression of dementia and virus reduction in the cerebrospinal fluid may even lead to a complete recovery of persons with dementia. ${ }^{14}$

If the elements of psychosis, agitation and mania are present, lower doses of atypical antipsychotics could be included in therapy. Additional support in therapy can be provided by reminder systems (eg. notebooks, signs, logs, and alarms), slow talking and reorientation.

\section{Delirium and HIV}

Delirium is a common diagnosis in patients with HIV infection, but it is rarely recognized. It occurs in all age groups. It can be caused from a range of disorders - drug intoxication, addiction and withdrawal symptoms, infections, metabolic disorders, fluid balance, electrolyte and acid base disorders, endocrine disorders, malnutrition and hypovitaminosis, neoplastic syndrome, neurological, hepatic, renal, pulmonary and cardiac diseases. However, delirium can be overseen because it often resembles other psychiatric disorders. Hypoactive delirium often resembles to depression, and hyperactive delirium often resembles to mania or psychosis. ${ }^{14}$

\section{Pain syndromes and HIV}

Pain is present in as much as $30-80 \%$ of patients infected with HIV. Pain may be a result of conditions associated with HIV, result of treatment side-effects or completely unrelated to HIV. Nerve damage - neuropathy is one of the possible consequences of antiretroviral therapy, although it may be caused by the direct action of the HIV virus. Peripheral neuropathy usually involves damage to the nerves in the feet, and rarely, even in the hands. Symptoms may include burning sensation, reduction of 
the sensations and even severe pain. In HIV-positive individuals, neuropathy can be caused by lack of vitamin B12. Opportunistic cytomegalovirus infection can also cause neuropathy. As a result of CART therapy, abdominal pain, headache and muscle pain can develop. Often, HIV patients who are experiencing pain are inadequately treated. ${ }^{15}$

\section{CONCLUSION}

Due to a rapid development of the science and research, an increased number of new HIV treatment drugs are discovered. It is very important that psychiatrists are informed about medications the patient is taking because of the possible interactions between drugs and their side effects. Most common interactions that should be considered are those between ritonavir (Norvir) and benzodiazepines and hypnotics. Clozapine and pimozide are contraindicated during CART. The most common side effects of CART are depression, metabolic abnormalities, lipodystrophy and gastrointestinal symptoms. Given that patients with AIDS live longer today, they are prone to psychological problems related to living with a chronic illness. Thus, psychiatric care is an essential part of a multidisciplinary treatment. The role of psychiatrists in the area of HIV treatment is to perform a variety of liaison activities associated with AIDS, such as lectures and educational programs for schools, health centers and high-risk groups such as drug users and homosexuals, education of medical students and medical personnel, confrontation with stigma, attendance of medical rounds with medical teams for AIDS, taking the lead in psychosocial teams for AIDS, and providing regular psychiatric help to the patients.

\section{PSIHIJATRIJSKI ASPEKTI AIDS-a}

Sažetak - AIDS je multimorbidna i komplicirana medicinska bolest praćena psihijatrijskim poremećajima i jakom stigmom, te diskriminacijom ljudi koji su inficirani. Standardna antiretroviralna terapija i kombinirana antiretroviralna terapija (CART) reducira smrtnost, ali incidencija pojave AIDS-a je u porastu. U svijetu je oko 34 milijuna ljudi inficirano HIV-om, a novih slučajeva AIDS-a godišnje je nešto manje od 4 milijuna u čitavoj populaciji. Hrvatska je zemlja koja kontinuirano ima nisku incidenciju te bolesti. S obzirom da pacijenti s AIDS-om danas uz terapiju dulje žive pojavljuju se psihološki problemi vezani uz kroničnu bolest tako da je psihijatrijska skrb esencijalni dio multidisciplinarnog liječenja.

Ključne riječi: AIDS, anksiozno-depresivni poremećaj, psihotični poremećaj, delirij, kognitivni poremećaji, bolni sindrom. 


\section{REFERENCES}

1. Cohen MA, Chao D. Comprehensive psychosocial and psychiatric diagnostic consultation in persons with HIV and AIDS. In: Cohen MA, Gorman JM, editors. Comprehensive textbook of AIDS psychiatry. New York (NY): Oxford University Press; 2008. p. 61-73.

2. Cohen MA. AIDSism, a new form of discrimination. Am Med News. 1989;32:43.

3. Organization of AIDS Psychiatry. Available from: http://www.apm.org/sigs/oap/.

4. Croatian National Institute of Public Health. Available from: http://www.hzjz.hr/epidemiologija/hiv.htm

5. Cohen MA. History of AIDS psychiatry - a biopsychosocial approach - paradigm and paradox. In:CohenMA,GormanJM, editors. Comprehensive textbook of AIDS psychiatry. New York (NY): Oxford University Press; 2008. p. 3-14.

6. Drug interactions. Available from: http://hivinsite.ucsf.edu.

7. Drug interactions. Available from: http://www. hiv-druginteractions.org.

8. Cohen MA, Weisman H. A biopsychosocial approach to AIDS. Psychosomatics. 1986; 27:245-249.
9. Cohen MA, Gorman JM. Comprehensive textbook of AIDS psychiatry. New York (NY): Oxford University Press; 2008.

10. Fernandez F, Ruiz P. Psychiatric aspects of HIV/AIDS. Philadelphia: Lippincott Williams \& Wilkins; 2006. p. 39-47.

11. CDC. Guidelines for prevention and treatment of opportunistic infections in HIV- infected adults and adolescents. Recommendations from CDC, the NIH and the HIV Medicine Association of the Infectious Diseases Society of America. MMWR. 2009; 58:1-5.

12. Ferrando SJ. Psychopharmacologic treatment of patients with HIV/AIDS. Curr Psychiatry Rep. 2009;11:235-242.

13. Cozza KL, Williams SG, Wynn GH. Psychopharmacologic treatment issues in AIDS psychiatry. In: Cohen MA, GormanJM, editors.Comprehensive textbook of AIDS psychiatry. New York (NY): Oxford University Press; 2008. p. 455-485.

14. Ances BM, Ellis RJ. Dementia and neurocognitive disorders due to HIV-1 infection. Semin Neurol. 2007;27:86-92.

15. Cohen MA, Alfonso CA. AIDS psychiatry: psychiatric and palliative care, and pain management. In: Wormser GP, editor. AIDS and other manifestations of HIV infection. 4th ed. San Diego: Elsevier Academic Press; 2004. p. 537-576. 